\title{
Analysis of Factors Influencing Sales on SHI-DA Semarang
}

\author{
Alvin Ferdian \\ Soegijapranata Catholic University \\ alvin.the.bull@gmail.com
}

\begin{abstract}
The purpose of this research is to know whether the use of offline (on-site) promotion, digital payment, Instagram, and Gofood/Grabfood have effect on the sales of SHI-DA Semarang. The research used a quantitative method in the form of action research. The analysis was conducted using multiple linear regression accompanying with t-test and F-test. This research was conducted at SHI-DA Semarang using sales data of December 2019 to March 2020 and respondents comprising of SHI-DA consumers for data on marketing programs. The results revealed that marketing through digital payment (e-wallet) has an effect on sales of SHIDA Semarang, while marketing programs through offline (on-site), Instagram, and Gofood/Grabfood individually had no effect on the sales of SHI-DA Semarang. Nevertheless, the promotions simultaneously show significant influence on the sales of SHI-DA Semarang. Thus, marketing programs through Offline (on-site) promotion, Gofood/Grabfood, and Instagram must be done simultaneously in order to have an effect on the sales of SHI-DA Semarang.
\end{abstract}

Keywords: Food Business, Sales Analysis, Digital Marketing.

\section{INTRODUCTION}

The online culinary business in Indonesia has grown in the recent years due to people's needs and lifestyle. Data from Parama Indonesia, the agency that helps start-up companies to grow, states that Indonesia's culinary sector has grown by an average of $7 \%$ to $14 \%$ annually in the last five years. The rise of the culinary business in Indonesia has caused higher competition and every company needs to maintain their customer loyalty for the customers continue to buy food from them (Junimas, 2017).

SHI-DA Indonesia, one of the Taiwanese hawker companies, experiences this competitive condition in its operation in Indonesia. It was established in 2011 and currently has more than 15 branches around Indonesia (SHI-DA Indonesia, 2020). SHI-DA Indonesia was 
promoted by young Indonesians who choose to become entrepreneurs. It sells Taiwanese street food that can be consumed at any time.

SHI-DA Indonesia is developed under a franchise system where each outlet may be owned by different person. It has two types of outlets, namely SHI-DA and SHI-DA Express, which are differentiated based on the menu. SHI-DA sells food and beverages, while SHI-DA Express sells only food. A branch in Semarang is SHI-DA Express (as of June 2019). The financial report of this branch shows that the sales growth is not equivalent to that of the other branches. The sales figure tends to stagnate and even is like to decrease, while sales of other branches as of July 2017 - July 2018 show an increase.

Lack of brand awareness of SHI-DA is possibly the cause of many people do not know SHI-DA and its products. This happens for especially branches outside Jakarta and therefore they experience uneven increase in their sales. Besides innovating the products and the sales system that can make customers interested in buying its products, increasing brand awareness of SHI-DA can become one of promotion strategies for SHI-DA Indonesia to deal with tighter competition at this time. Promotion strategy should not only promote the products but also the brand. A brand makes buyers to recognize the product easily and can be used as a differentiator of a product from the others. Therefore, the promotion has to be focused on the brand of SHIDA so that consumers acquaint with the brand better.

Young people who are the target market of SHI-DA use social media and various internet-based means to find information. They look for information on food and place to eat from various social media and make purchasing decision based on a review on a video in their Instagram account. A good review will usually create their interest to trying the food or the place. Otherwise, a not good one will make them to be reluctant to try and are less likely to recommend the food or the place to others. In other words, good reviews on the product will 
likely to increase sales and brand recognition. SHI-DA Indonesia in Semarang has been utilizing online (Instagram) and offline media for their promotions.

In addition, digital payment are increasingly rampant nowadays, especially since the use of Ovo and Gopay offers a variety of cashback for the users. Ovo's and Gopay's cashback drive buyers to buy at stores offering the promotion. Similarly, SHI-DA Indonesia has also worked with Ovo and Gopay to attract buyers using the cashback programs provided. Moreover, SHIDA Indonesia also offers on-site promo programs by giving discounts for on-site purchases with cash payments. Accordingly SHI-DA Indonesia in Semarang has also implementing digital and offline (direct) for their payment system to attract more consumers.

This study aims to determine the impact of online and offline promotions on sales of SHI-DA Indonesia in Semarang. In more particularly, the study wants to know whether there is influence of offline promotion (on-site) and promotions on Instagram on the sales of SHIDA Semarang.

\section{LITERATURE REVIEW}

Brand plays an important role in influencing brand purchasing decisions. It also plays an essential role in influencing consumer purchasing decisions for a product (Wibowo, 2017). Thus, brand awareness is important for the success of a product in the market. Brand awareness is the ability of a potential buyer to know a brand that is part of a product category (Wibowo, 2017).

To make buyers or potential buyers to know the brand, programs for promoting the brand are needed. There is a wide variety of promotional media ranging from conventional media (offline) to unconventional media (online). According to Amaliah et al. (2015), promotional media is a tool or mean used for promotional purpose. Promotional media is 
divided into several categories: conventional print media, print media advertising, outdoor media, online media, and electronic media.

The use of online media and electronic media indicates that the company does digital marketing. According to Sanjaya and Tarigan (2009), digital marketing is a marketing activity including branding that uses websites, blogs, or social media. Kotler and Keller (2012) stated there are three best strategies for marketing products online: website, social media, and word of mouth marketing. Among others, social media Instagram has gain its popularity for promoting products in especially culinary business. Instagram is an application focusing more on photos or videos posted by the Instagram account owner (Handika \& Darma, 2018).

According to Tazkiyyaturrohmah (2018), an electronic payment application is used to make electronic money payments. It can now be used on mobile devices and can be downloaded directly on android (Google play), IOS (Apple store), and other smartphones. The mobile application works like a money storage wallet (digital cash) that makes it ready for transaction easily, quickly, and safely. The JakPat survey in the Startup Report 2017 resulted in the most popular electronic money and most popular one is Gopay ID available in the Gojek app.

\section{METHODS}

This research uses quantitative action research method and adressed SHI-DA Indonesia located in Semarang. All SHI-DA consumers in Semarang (herewith called SHI-DA Semarang) is thus the population of this study. Purposive sampling was used for selecting samples from which the data was collected. The number of samples used in this study amounted 40 respondents that is considerably suitable and sufficient for a minimum use. The data collection method was questionnaires distributed to consumers of SHI-DA Semarang who use digital payment methods on transactions with SHI-DA Semarang. Data of sales was secondary data 
gathered from the company. The sales data used was those during December 2019 to March 2020.

According to the purpose of the study, the impact offline (on-site) promotion, Instagram promotion, and digital payment to sales was analyzed using Multiple Linear Regression. The independent variables are offline (on-site) promotion $\left(\mathrm{X}_{1}\right)$ measured promotional costs incurred in doing so, digital payment $\left(\mathrm{X}_{2}\right)$, Instagram $\left(\mathrm{X}_{3}\right)$, Gofood/Grabfood $\left(\mathrm{X}_{4}\right)$. The dependent variable is sales of SHI-DA Semarang. Hypothesis tests was conducted partially using t-test and simultaneously using F-test.

\section{RESULTS AND DISCUSSION}

\section{The Company's Marketing Media and Payment Method}

Offline (on-site) promotion run by SHI-DA Semarang is "BUY 1 Get 1 Free" which is offered at every the 1 st to 5 th each month. The promotion that has been running since October 2018 applies for purchasing crispy chicken sharing size that is given crispy chicken mini size for free. Buyers' response to this promotion was quite good and more consumers were encouraged to buy crispy chicken sharing size. The promotion was able to contribute $8 \%$ of the total sales during March 2020, while the total costs incurred was only $2 \%$ of the total sales.

Promotion using the SHI-DA Semarang's official Instagram account was to advertise SHI-DA's products to be better known. During the Instagram promotion conducted at $21-28$ March 2020, the costs incurred amounted 2\% of the total sales, which covered costs of ads used by SHI-DA Semarang. There were two types of ads used. The first ad was at $21-25$ March 2020, which was done daily at the cost of Rp.50.000,00 per ad and the duration of delivery per ad is 24 hours. The second one was the ad that took place on 26-28 March 2020 that was done daily at the cost of $\$ 3.30$ per ad. 
Based on the sales data, sales from digital payments accounted for $21 \%$ of the total sales of SHI-DA Semarang during March 2020, with the total costs incurred was $0.31 \%$ of the total sales. Meanwhile, sales from Gofood/Grabfood accounted for $12 \%$ of the total sales with the cost of $2 \%$ of total sales.

\section{Multiple Linear Regressions}

The result of multiple linear regression conducted with SPSS is presented in table 1. Among the independent variables, only Instagram $\left(\mathrm{X}_{3}\right)$ provides negative influence on sales which means sales increases as cost of conducting promotion on Instagram decreases.

Reviewing the result on $t$ test using threshold $t$ table value of 2.056 at $5 \%$ of $\alpha$, it can be concluded that only the varable of digital payment $\left(\mathrm{X}_{3}\right)$ significantly influences sales of SHIDA Semarang (calculated $t$ of $4.805>t$ table of 2.056). The variables offline (on-site) promotion $\left(\mathrm{X}_{1}\right)$, Instagram $\left(\mathrm{X}_{3}\right)$, and Gofood/Grabfood $\left(\mathrm{X}_{4}\right)$ were found as having no influence on sales of SHI-DA Semarang since their calculated $t$ is less than $t$ table of 2.056 (respectively $1.734,-1.028,1.747)$.

Table 1. Multiple Linear Regressions

\begin{tabular}{|c|c|c|c|c|c|c|}
\hline \multirow[b]{2}{*}{ Mod } & & \multicolumn{2}{|c|}{$\begin{array}{l}\text { Unstandardized } \\
\text { Coefficients }\end{array}$} & \multirow{2}{*}{$\begin{array}{c}\text { Standardized } \\
\text { Coefficients } \\
\text { Beta }\end{array}$} & \multirow[b]{2}{*}{$\mathrm{t}$} & \multirow[b]{2}{*}{ Sig. } \\
\hline & & $\mathrm{B}$ & Std. Error & & & \\
\hline \multirow[t]{5}{*}{1} & (Constant) & 190351.699 & 55312.961 & & 3.441 & .002 \\
\hline & Offline (on-site) promo & 2.782 & 1.605 & .234 & 1.734 & .095 \\
\hline & Digital payment & 130.546 & 27.170 & .643 & 4.805 & .000 \\
\hline & Instagram & -3.312 & 3.221 & -.142 & -1.028 & .313 \\
\hline & Gofood/Grabfood & 5.374 & 3.075 & 241 & 1.747 & .092 \\
\hline
\end{tabular}

a. Dependent Variable: Sales

Based on the result of $\mathrm{F}$ test presented in table 2, offline (on-site) promotion, digital payment, Instagram, and Gofood/Grabfood influence simultaneously sales of SHI-DA Semarang since the value of calculated F (12.578) is bigger than F table of 2.74. 
Table 2. ANOVA test on Offline (on-site) Promotion, Digital Payment, Instagram,

\begin{tabular}{lll|r|r|c|r}
\hline \multicolumn{7}{c}{ Gofood/Grabfood } \\
\hline \multirow{2}{*}{1} & Sudel & \multicolumn{1}{c}{ Sum of Squares } & \multicolumn{1}{c}{ df } & Mean Square & \multicolumn{1}{c}{ F } & \multicolumn{1}{c}{ Sig. } \\
\cline { 2 - 8 } & Regression & 2531363070736.646 & 4 & 632840767684.162 & 12.578 & $.000^{\mathrm{b}}$ \\
\cline { 2 - 8 } & Residual & 1308155122811.739 & 26 & 50313658569.682 & & \\
\hline
\end{tabular}

a. Dependent Variable: SALES

b. Predictors: (Constant), Offline (on-site) promotion, Digital payment, Instagram, Gofood/Grabfood

The t-test and F test show that only digital payment influences the sales of SHI-DA

Semarang. However, all marketing programs simultaneously influence on sales of SHI-DA

Semarang. This means that if all the marketing programs conduted together, they have effect on sales of the company.

Testing the result by eliminating the variable of digital payment that is partially influence sales, similar result as preented in table 3 is still existed. The result shows that offline (on-site) promotion, Instagram, and Gofood/Grabfood simultaneously influence sales of SHIDA Semarang since counted F of 4.992 is bigger than F table of 2.96. In other words, it can be concluded that if the three marketing programs (offline (on-site) promotion, Instagram, and Gofood/Grabfood) are conducted simultaneously, they significantly influence the sales of SHIDA Semarang.

Table 3. ANOVA test) on Offline (on-site) Promotion, Instagram, and Gofood/Grabfood

\begin{tabular}{|c|c|c|c|c|c|c|}
\hline Model & & $\begin{array}{l}\text { Sum of } \\
\text { Squares }\end{array}$ & $\mathrm{df}$ & Mean Square & $\mathrm{F}$ & Sig. \\
\hline \multirow[t]{3}{*}{1} & Regression & $\begin{array}{r}136979460724 \\
8060\end{array}$ & 3 & 456598202416 & 4.992 & $.007^{b}$ \\
\hline & Residual & $\begin{array}{r}246972358630 \\
0.325\end{array}$ & 27 & $\begin{array}{r}91471243937 . \\
049\end{array}$ & & \\
\hline & Total & $\begin{array}{r}383951819354 \\
8.385\end{array}$ & 30 & & & \\
\hline
\end{tabular}

a. Dependent Variable: ONSET

b. Predictors: (Constant), Offline (on-site) Promotion, Instagram, Gofood/Grabfood 


\section{CONCLUSIONS AND IMPLICATIONS}

Based on the results, it can be concluded that digital payments has significant effect on sales of SHI-DA Semarang. It indicates that if SHI-DA Semarang offers digital payment (ewallet) in their payment method, consumers may have interest to buy their products. Other programs (offline (on-site) promotion, Instagram ads, and Gofood/Grabfood) individually are not able to encourage consumers to buy SHI-DA's products. Nevertheless, they simultaneously influence sales of SHI-DA Semarang, which means that each of them has effect on sales when they are used together.

As digital payment is found as having significant influence on the sales, future research may examine the influence using different number of digital payment. More specifically, will the influence still be significant if more or less media of digital payment are applied. Future research may also examine the influence using more variables of advertisement, whether sales is significantly affected.

\section{REFERENCES}

Amaliah, Fianto, and Yosep (2015). Perancangan Media Promosi PT Petronika sebagai Upaya Pembentukan Citra Perusahaan. Jurnal Desain Komunikasi Visual, 4(1), Accessed from https://jurnal.dinamika.ac.id/index.php/ArtNouveau/article/view/768/0

Handika, Made Resta dan Darma, Gede Sri (2018, April). Strategi Pemasaran Bisnis Kuliner Menggunakan Influencer Melalui Media Sosial Instagram. Jurnal Manajemen dan Bisnis, 15(2), Accessed from http://scholar.google.co.id/scholar_url?url=http://journal.undiknas.ac.id/index.php/magi stermanajemen/article/view/601/370\&hl=en\&sa=X\&ei=2k3LXKGo7gygS59oeICg\&sci $\underline{\text { sig=AAGBfm0mx_r4e81ddYxie5QLwtjlmnJYg\&nossl=1\&oi=scholarr }}$

Kotler, P. and Keller, K. (2012). Marketing Management. $14^{\text {th }}$ Edition. Upper Saddle River: Prentice Hall, Inc.

Sanjaya, R dan Tarigan, J. (2009). Creative Digital Marketing: Teknologi Berbiaya Murah, Inovatif, Dan Berdaya Hasil Gemilang. Jakarta: Elex Media Komputindo.

SHI-DA Indonesia (2019). www.SHI-DAindonesia.com/story.html 
Tazkiyyaturrohmah, R. (2018, May). Eksistensi Uang Elektronik Sebagai Alat Transaksi Keuangan Modern. Muslim Heritage, 3(1), Accessed from http://jurnal.iainponorogo.ac.id/index.php/muslimheritage/article/download/1240/878

Wibowo, N. E. (2017, August). Pengaruh Brand Awareness Terhadap Keputusan Pembelian (Studi Kasus Pada Yellow Truck Cabang Sunda Bandung. e-Proceeding of Applied Science, 3(2), Accessed from https://openlibrary.telkomuniversity.ac.id/pustaka/135786/pengaruh-brand-awraenessterhadap-keputusan-pembelian-studi-kasus-yellow-truck-cabang-sunda-bandung-.html

Yaumi, M. and Damopoli, M. (2014). Action Research: Teori, Model, dan Aplikasi. Edisi Pertama. Jakarta: Kencana [online]. Accessed from https://books.google.co.id/books?hl=en\&lr=\&id=X-

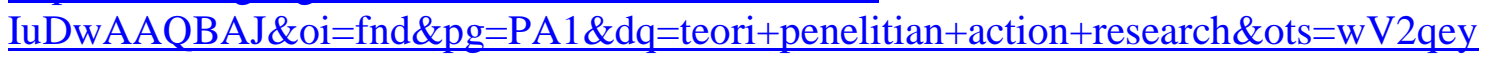
NPIi\&sig=GU 7aUq7unLMPEw-

1ZqmF9nfpMw\&redir_esc=y\#v=onepage \&q=teori\%20penelitian\%20action\%20researc $\underline{\mathrm{h} \& \mathrm{f}=\text { false }}$ 